\title{
VARIAÇÃO GENÉTICA E FENOTÍPICA DAS SEMENTES DE UMA PALMEIRA EM REMANESCENTES DA MATA ATLÂNTICA
}

\section{Marilia Souza Lucas ${ }^{1}$ \\ Carolina da Silva Carvalho ${ }^{2}$ \\ Marina Corrêa Côrtes ${ }^{3}$}

\begin{abstract}
Resumo: A Mata Atlântica tem sido impactada pela perda de habitat e fragmentação, afetando dispersores de sementes, com os grandes frugívoros sendo os primeiros a desaparecer. A extinção local pode influenciar a estrutura espacial, demográfica e genética de espécies com frutos carnosos. O objetivo foi testar a hipótese de que a dispersão de sementes de Euterpe edulis e de seus genes é mais limitada em áreas fragmentadas, onde os grandes frugivoros foram extintos, do que em áreas preservadas, e associar esta perda à redução do tamanho das sementes. O trabalho foi conduzido em duas áreas fragmentadas e em duas áreas de reserva. Para avaliar a diversidade genética foram comparados os parâmetros de heterozidozidade, riqueza alélica e Fis entre adultos reprodutivos e sementes dispersas, utilizando oito marcadores de microssatélites. Não foram encontradas diferenças na diversidade genética entre adultos e sementes ao se comparar áreas fragmentadas e defaunadas e reservas, porém o tamanho das sementes se mostrou menor nos fragmentos.

Palavras-chave: Diversidade genética; Fragmentação; Dispersão de sementes; Fenótipo.
\end{abstract}

\footnotetext{
1 Ciências Biológicas/Unesp - Universidade Estadual Paulista "Júlio de Mesquita Filho", Brasil. E-mail: marilia_souza2@hotmail.com.

2 Ciências Biológicas/Unesp - Universidade Estadual Paulista "Júlio de Mesquita Filho", Brasil. E-mail: carolina.carvalho@ymail.com.

3 Ciências Biológicas/Unesp - Universidade Estadual Paulista "Júlio de Mesquita Filho", Brasil. E-mail: marina.ccortes@gmail.com.
} 